\title{
EVALUATION OF DEVELOPMENT AND EFFICIENCY OF RENEWABLE ENERGY SOURCES IN NORDIC COUNTRIES OF THE EUROPEAN UNION
}

\author{
Dominika Ceryova, Stefaniia Belinska, Natalia Turcekova, Izabela Adamickova, Peter Bielik \\ Slovak University of Agriculture in Nitra, Slovakia \\ dominika.ceryova@uniag.sk
}

\begin{abstract}
Renewable energy sources (solar, hydropower, wind, geothermal energy, and biomass) are an alternative to fossil fuels. Using renewable energy sources, in addition to environmental benefits (e.g., reducing air pollution and greenhouse gas emissions), allows to improve the economic (e.g., increasing the state's independence from fuel and energy imports) and social (e.g., job creation) situation of countries. The cumulative effect of these benefits is the reason for the European Union support for renewable energy sources. The object of the research is the Scandinavian (or Nordic) member states of the European Union, which from all member states have made the most significant contribution to the value of gross finally energy consumption from renewable sources in the European Union. These countries - Sweden, Finland, and Denmark - have on a long-term basis a large share of production from renewable sources. Due to the availability and variety of data, a basic data set was created, which represents data for five monitored indicators per capita of the renewable energy sector in the period 2009-2016. The results of the research part indicate the development tendency of these indicators and their statistically significant corelation using nonparametric statistical methods (such as Kruskal-Wallis test, Friedman test and Spearman's correlation coefficients). Most indicators developed very fluctuating (an exception was an indicator "electricity capacity" - increasing rate). An indicator "investments from public financial institutions" was unsystematical (the largest amount in Denmark - 60 dollars per capita, in Finland 5.6 dollars per capita and in Sweden 36 dollars per capita). Stochastic frontier analysis (SFA) model in the logarithmic form of Cobb-Douglas production function allowed to estimate the output-oriented technical efficiency of conversion inputs into output and compare it with other member states of the European Union. Finland has the highest level of technical efficiency $(\mathrm{TE}=0.62)$, followed by Sweden $(\mathrm{TE}=0.60)$ and the lowest by Denmark $(\mathrm{TE}=0.44)$. In comparison to other European Union countries, the monitored countries are included in the same ranges of estimated technical efficiency as most European Union countries.
\end{abstract}

Keywords: Nordic countries, renewable energy, nonparametric statistical methods, SFA model, development, efficiency

\section{Introduction}

Scandinavian or Nordic countries are among the leaders in the production and consumption of energy from renewable sources. They are playing a leading role in diffusion and diversification of renewable energy technologies: Sweden in wind power, hydropower and forest biomass technologies, Finland in forest biomass technologies, and Denmark in wind power. Power generation from renewable energy sources, such as wind and solar photovoltaic, solar thermal, geothermal and biomass, can deliver over $90 \%$ of the energy-related $\mathrm{CO}_{2}$ emission reductions needed by 2050 , when combined with improved energy efficiency [1].

The Scandinavian countries are at the forefront of the global energy innovation market. This is facilitated by government support programs that stimulate investment in local industry, build capacity at the firm level, and promote education and training for the workforce. The benefits of using renewable energy sources are not only energy independence and security, reduction in greenhouse gas emissions, the diversification of energy supplies, an improvement in the environment, but also the creation of new jobs, an increase in the well-being of the population and profit from the export of technologies and equipment.

Sweden, Denmark, and Finland are energy intensive countries because of cold climate, energy intensive industries, wide sparsely populated areas with long distances, and high standard of living [2]. But at the same time, these countries are the first in the list of the most environmentally friendly countries in the European Union. According to Eurostat in Sweden (56.4\%), Denmark (43.1\%) and Finland (37.2\%) share of energy from renewable sources in gross final energy consumption are higher than the average (18.9\%) and target values (20\%) in the EU in 2019 [3].

In 2016, Sweden announced a goal to create $100 \%$ renewable energy no later than 2040. And by 2045 , it plans to become the first zero carbon emissions industrial power. The country's power system is almost entirely decarbonized already, based on extensive hydropower resources and nuclear power, 
as well as district heating fuelled by biomass [1]. Sweden uses quota and tax pressure mechanisms to stop using fossil fuels. Biofuels are exempt from energy and environmental taxes. Climate friendly and market-based policies, and support for innovation contribute to supporting production energy from renewable sources. In Sweden energy transition policies can accompany strong economic growth and environment sustainability. Sweden has built a sustainable energy system using its own local renewable resources. From an importer of electricity, it has become an exporting country, supplying surplus energy to other European countries.

Denmark is the world leader in wind energy production per capita. Growing wind capacities are affecting wholesale electricity prices in and are resulting in changes in the value of wind energy itself. These changing costs and benefits are affecting the economic performance of new wind projects [4]. In Denmark, the state is working with business to achieve common goals in the energy sector, and to fulfil the commitments of the UN Sustainable Development Goals. In Denmark government also wants to become a $100 \%$ fossil-free economy by 2050 , in order to mitigate climate change, and gain socioeconomic benefits from regeneration and strengthening the resilience of regional and rural communities. [5]. Denmark intends to ban burning of coal and oil products at power and heat plants no later than 2030, leaving only gas permissible from fossil fuels. Denmark is a country with the high degree of wind energy integration, the widespread use of biomass, the environmentally progressive system of energy taxation and leadership in the process of reducing the carbon footprint [6].

Finland was a country dependent on imported electricity. But the government has begun to invest in research and development to generate energy from its own natural forest resources. This led to the emergence of several new technologies, such as the production of bioethanol from wood and straw. In Finland, forest energy consists of significant amounts of woodbased fuels, which are utilized for CHP production and heat production [7]. Seasonality also affects the availability of solar, wind and hydropower resources, making the need for energy storage highly relevant in Finland [8]. Finland supports renewable energy producers with green tariffs and reduced taxes on greenhouse gas emissions. There are also heat bonuses for biogas and woody biomass. Seasonality also affects the availability of solar, wind and hydropower resources, making the need for energy storage highly relevant. The environmental impacts of most of the renewable energy sources in Finland are rather small both at the unit process level, as well as at the 2020 target levels [7]. Main negative environmental impacts relate to the use of forest energy. Government should take it into consideration, when develops the optimal and flexible energy-mix in Finland. Variable renewable energy sources and energy storage solutions can play a significantly role in a future energy system for Finland based on $100 \%$ renewable energy generation [9].

In the EU, it is becoming a central field of policy. Energy from RES bringing together a multitude of objectives related to geopolitics, economic competitiveness, sustainable development, environmental concern, and the low-carbon transition [10]. Nordic countries use the low carbon energy-generating sources, such as renewable energy sources, by implementing higher levels of technology, because they are oriented on the impact of globalization on environmental [11]. Expanding the use of renewable energy sources in Scandinavian countries will contribute to economic development, achievement of sustainable energy effectiveness goals, help create jobs, improve health and climate, and significantly contribute to the achievement of the sustainable development goals (SDGs) 2030 [12].

The first main aim of this paper was to find out the development tendency and dependence of selected indicators of the renewable energy sector in the Nordic countries of the European Union (such as electricity generation, electricity capacity, investments from public financial institutions, number of employees and turnover from economic activity - all expressed "per capita"). The dependence between them was investigated using statistical tests. The second main aim was to find out, if the Nordic countries converted their inputs (electricity capacity, investments from public financial institutions and number of employees) into output (electricity generation) effectively using SFA.

Due to the availability and variety of data, a basic data set was created, which represents data for five monitored indicators per capita of the renewable energy sector in the period 2009-2016 (more upto-date data were not complete for all countries, but some of them are mentioned in the discussion). 


\section{Materials and methods}

The object of this paper was the Nordic countries of the European Union in the period 2009-2016 in terms of the situation with renewable energy (wind + biomass + solar + geothermal + hydropower energy). Data were obtained from IRENA (International Renewable Energy Agency) and EUROSTAT (Statistical Office of the European Communities).

The basic file represents data in the following structure (selected renewable energy indicators):

- electricity generation (MWh per capita),

- electricity capacity (MW per capita),

- investments from public financial institutions (USD per capita),

- number of employees (n per capita),

- turnover achieved from the economic activities related to production, distribution, installation,

- operation and maintenance of equipment (USD per capita).

$1^{\text {st }}$ main aim

Non-parametrical statistical methods were used in the statistical processing of the data set:

- Kruskal-Wallis test

$$
H=\frac{12}{N(N+1)} \sum_{i=1}^{k} \frac{R_{i}^{2}}{n_{i}}-3(N+1) ;
$$

- Friedman analysis of variance

$$
F=\frac{12}{n k(k+1)} R-3 n(k+1) ;
$$

- Spearman correlation coefficient

$$
\rho=1-\frac{6 \sum_{i=1}^{n} d_{i}^{2}}{n\left(n^{2}-1\right)} .
$$

\section{$2^{\text {nd }}$ main aim}

SFA model in the logarithmic form of Cobb-Douglas production function estimated how efficiently the Nordic countries of the European Union converted their inputs (electricity capacity, investments from public financial institutions and number of employees) to output (electricity generation).

The number of observations that entered the model was 2016 in 27 groups (European Union countries - except Croatia, which was a member state of the European Union from 2013) over a period of 8 years (2009-2016).

$$
\ln y_{i t}=\beta_{0}+\sum_{i=1}^{n} \beta_{n} \ln x_{n i t}+v_{i t}-u_{i t} \text {. }
$$

\section{Results and discussion}

\section{Non-parametrical statistical methods}

\section{Denmark}

The values of two selected indicators in the field of renewable energy sources, "electricity generation" and "electricity capacity" had a growing character in Denmark from year to year (wind and biomass energy sectors contribute the most). Cross et al. (2021) agree and add that Denmark has the greatest focus on biomass electricity of all the Nordic countries [13]. The authors Sovacoola and Tamboa (2016) state that the highest of wind energy integration (together with the widespread use of biomass) seems to support the contention that Denmark is a "green" state [6]. For comparison, the latest information of the Ministry of Foreign Affairs of Denmark says that Denmark generated half of its electricity from wind and solar power in 2019, what is the highest number ever [14]. "Investments from public financial institutions" have developed unsystematically throughout the period under review (as in the most countries of the European Union, for the comparison). The largest amount was invested in 2011 from the National Investment Bank in Ghana - 60 dollars per capita. The amount of money, in the 
form of a loan, was provided for construction of a wind farm with 111 turbines - one of the largest wind farms in the world. Spodniak et al. (2021) confirm our results with an argument that Denmark is a pioneering and well-researched country that was able to integrate a large share of wind power into a system [15]. Most employees (with fluctuating character) were employed in the already mentioned wind energy sector. Corsatea (2014) states, based on her results, that Denmark might reflect a falsely inflated job per MW ratio, because Denmark is a country specialized in the technology-manufacturing sector (high job rate) with most of the components exported (low local deployment) [16]. Based on the "p" values, we can state that a statistically significant dependence was demonstrated in the development of the "electricity generation" and the "electricity capacity" throughout the period under review. In both cases, there was a strong correlation based on the values of the Spearman correlation coefficient.

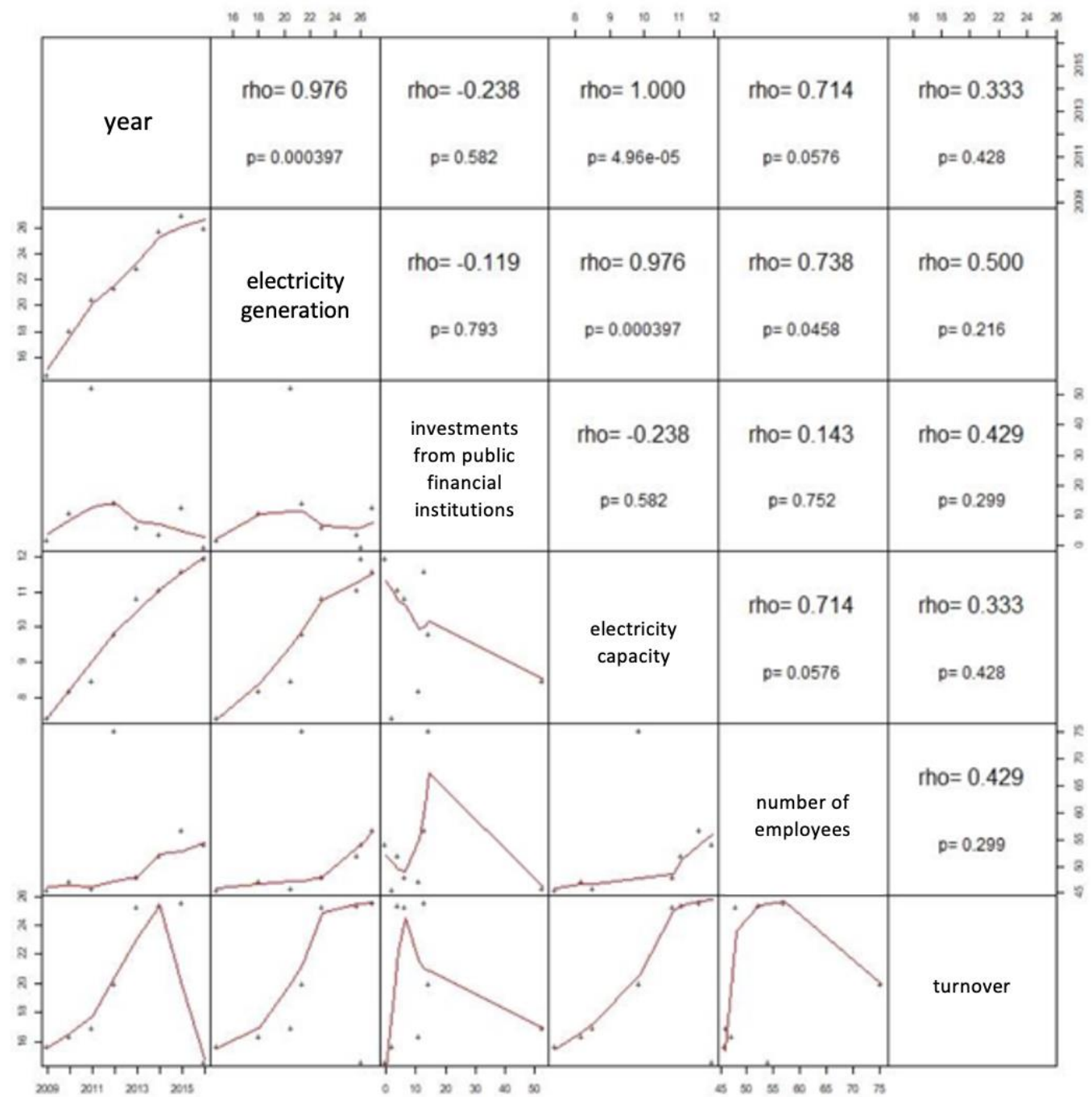

Fig. 1. Denmark

\section{Finland}

In Finland, we can state that all renewable energy sector's indicators had a fluctuate character throughout the period under review. The curve which is showing the development trend, indicates an increase in the future - except for the indicator of the electricity generation from renewable energy sources - we can see a slight decrease. For example, the results of regression analysis of Unger et al. (2017) show the negative effect of increased electricity generation from renewable energy sources on electricity prices in Finland [17]. Investments from public financial institutions ranged from 4 to 5.6 dollars per capita each year.

The largest amounts were invested in the wind, biomass, and hydropower energy sectors (Kilpeläinen, 2020 confirm this result [18]) during the whole period under review. Finland had the most installed electricity capacity in these mentioned sectors and produced the most renewable energy (there was not statistical dependence between investments from public financial institutions and installed 
electricity capacity either between investments and electricity generation based on the "p" values). The statistically significant dependence was confirmed in the relationship between the time period and installed electricity capacity - strong correlation.

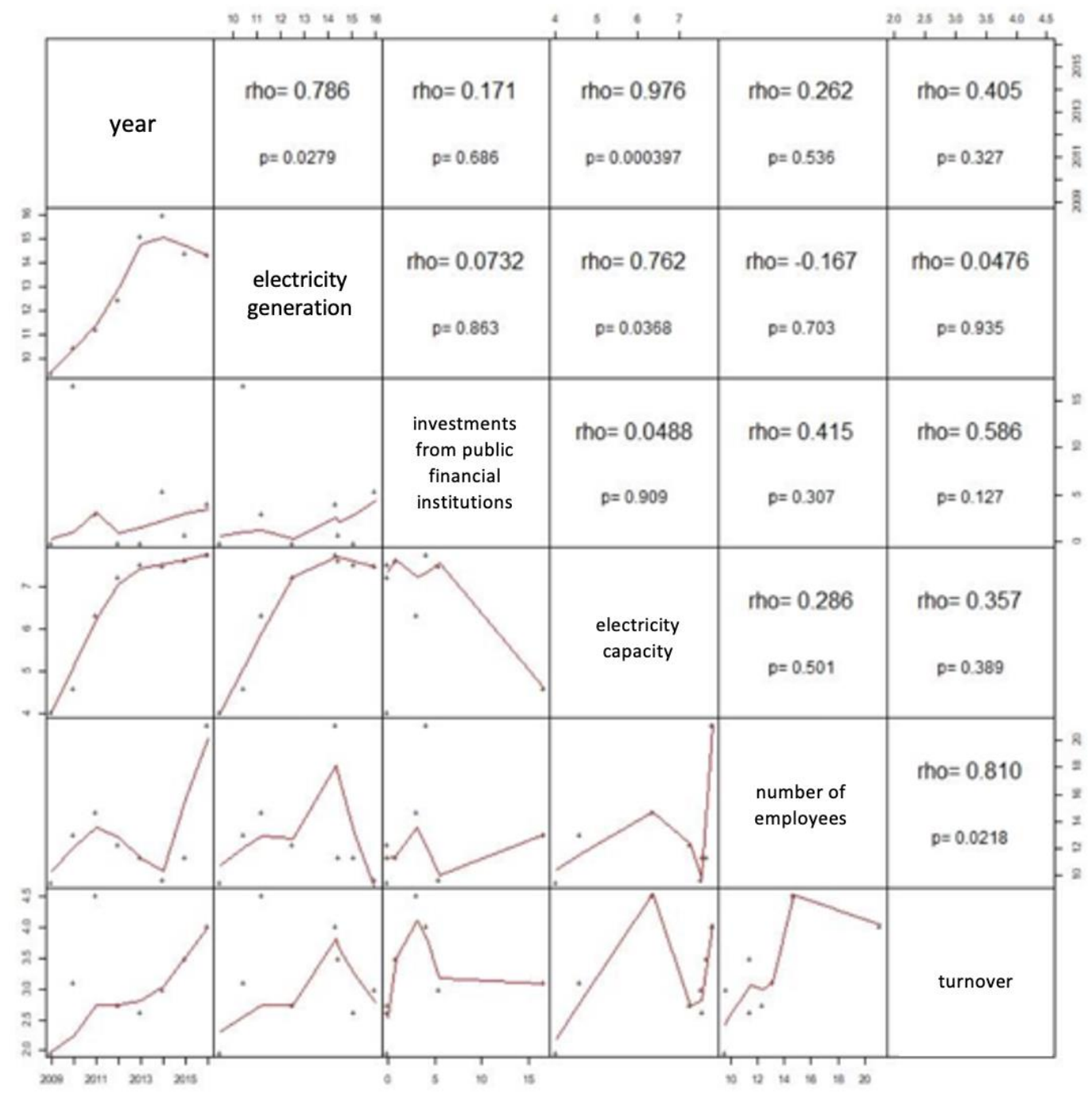

Fig. 2. Finland

\section{Sweden}

Investments from public financial institutions have developed unsystematically. The wind and biomass energy sector were supported the most during the whole monitored period. The latest data from the International Renewable Energy Agency (November 2019) show that in 2017 and 2018, the most money was invested in the wind energy sector, too [19]. Wind energy consumption forecasts by Sadorsky (2021) for 2018-2025 show that the wind energy consumption is the highest for Sweden [20]. The most investments were provided by the European Investment Bank and the National Investment Bank in Sweden in 2014 year - 35 dollars per capita and at least in 2009 year, when the value was so low that it approached zero when we calculated this value per capita.

The statistically significant dependence on investments from public financial institutions, either in terms of their development over time or in terms of their development in comparison with other indicators we did not record, because all values of the significance indicator are higher than the significance level of 0.05 . In the turnover achieved from the economic activities related to production, distribution, installation, operation, and maintenance of equipment we can observe the highest value in 2010 (1087 dollars per capita). The largest amount was represented by the economic activity in the biomass energy sector. Installed electricity capacity developed over time with an increasing tendency. Other indicators showed a fluctuating character. 


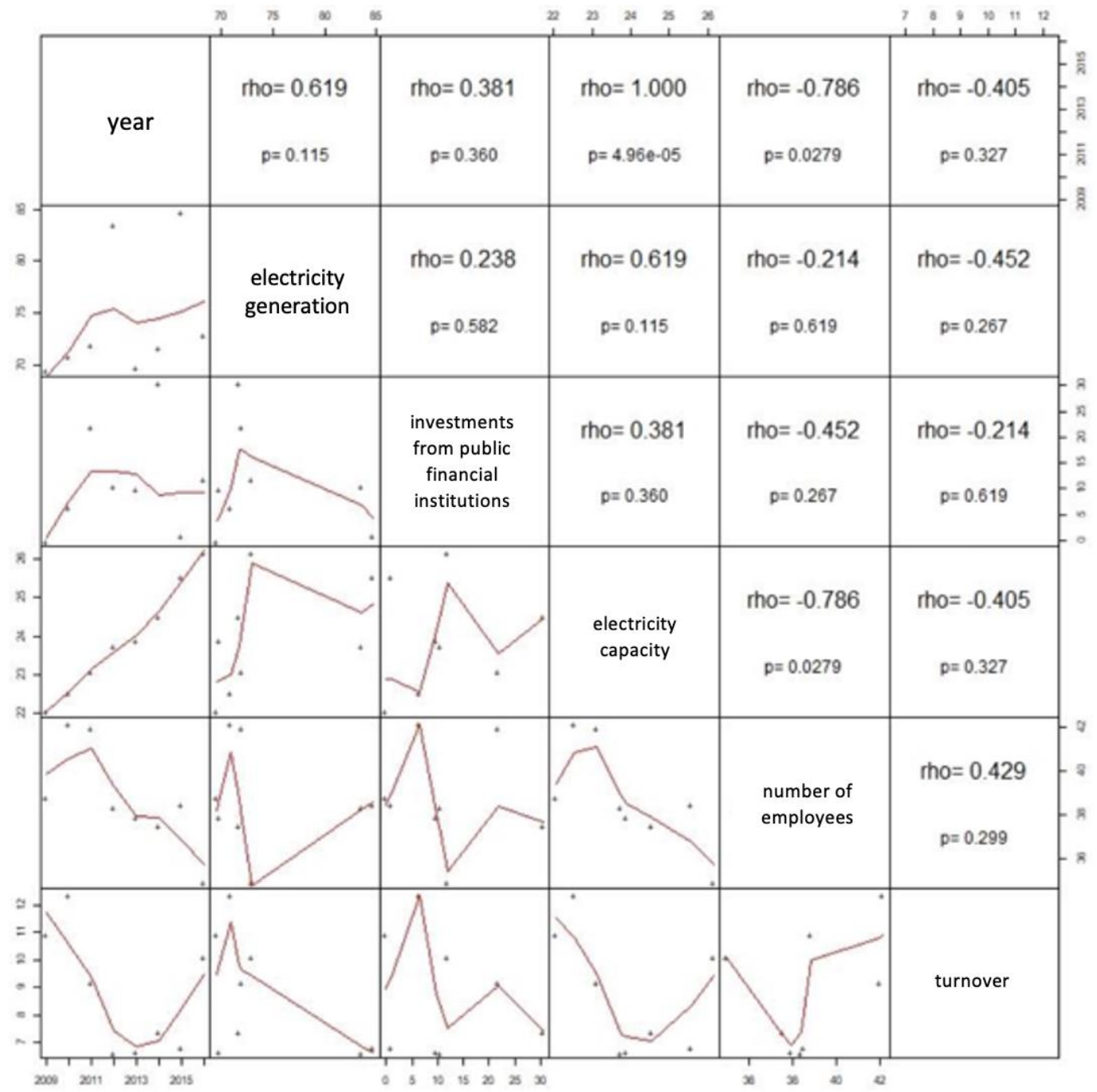

Fig. 3. Sweden

\section{SFA model}

The output-oriented technical efficiency for the Nordic countries of the European Union were estimated by SFA model (year 2016 was chosen for a deeper analysis). All European Union member states (except Croatia) entered to the model together with the Scandinavian countries.

Based on the results of the estimated output-oriented technical efficiency, all countries were classified into 9 groups (range $0.00-1.00$ ):

- 01 . group $0.00-0.10$ (5 countries)

- 02. group $0.11-0.20$ (1 countries)

- 03 . group $0.21-0.30$ ( 0 countries $)$

- 04 . group $0.31-0.40$ ( 2 countries $)$

- 05 . group $0.41-0.50$ (8 countries)

- 06. group $0.51-0.60$ ( 7 countries)

- 07. group $0.61-0.70$ (4 countries)

- 08 . group $0.71-0.80$ ( 0 countries $)$

- 09. group $0.81-0.90$ ( 0 countries $)$

- 10. group $0.91-1.00$ ( 0 countries $)$

Countries, which had not changed the output - electricity generation from renewable energy sources with regard to inputs, because their output-oriented technical efficiency $=1$, were considered as model countries (in our results a model country missing). 
Denmark belonged to the largest group ( $5^{\text {th }}$ group) together with other 7 European Union countries. The estimated output-oriented technical efficiency shown, that if Denmark will invest an unchanged amount from public financial institutions and electricity capacity and the number of employees will not be changed, the electricity generation would have to increase by $56 \%$ and Denmark will become efficient $(\mathrm{TE}=0.44)$.

Sweden was the part of the $6^{\text {th }}$ group. Its estimated output-oriented technical efficiency has shown that with unchanged inputs Sweden would have to increase electricity generation by $40 \%$ to become technically efficient $(\mathrm{TE}=0.60)$.

The $8^{\text {th }}, 9^{\text {th }}$ and $10^{\text {th }}$ groups were without countries, so we rank the most effective countries in the $7^{\text {th }}$ group. This group included Finland. Finland would have to increase electricity generation by $38 \%$ to make it a model country.

Most scientific papers deal with this issue in terms of environmental efficiency. For example, Cicae et al. (2014) used the Kaya econometric model for calculation, where indicators of energy intensity, carbon dioxide intensity, gross domestic product and investment were applied as input data [21].

\section{Conclusions}

We monitored the development trend and dependence separately in the Nordic states of the European Union. Selected indicators were electricity generation, investments from public financial institutions, electricity capacity, turnover from economic activities and the number of employees in the renewable energy sector. Indicators were expressed per capita. We used the following tests to solve the formulated problem: Kruskal-Wallis test for analysis of variance of dependent variables and Friedman test for analysis of variance of independently variables. As part of the evaluation of selected indicators, we focused on finding their correlations using Spearman correlation analysis. Based on the achieved results, we concluded that most indicators developed at a very fluctuating pace. An exception was the installed capacity of the equipment, which developed at an increasing rate over the years, and the mentioned dependence was also statistically significant. Investments from public financial institutions were unsystematic.

Based on the results of the SFA model and the estimated output-oriented technical efficiency, we can state that there was not one of the Nordic countries of the European Union that could be described as a model in terms of converting inputs into outputs (TE of countries was not equal to 1) and all countries would have to increase the energy generation from renewable energy sources when the inputs stayed unchanged. Finland had the highest level of technical efficiency $(\mathrm{TE}=0.62)$, followed by Sweden $(\mathrm{TE}=0.60)$ and the lowest by Denmark $(\mathrm{TE}=0.44)$.

Based on the achieved results, we considered the support of renewable energy sources by public financial institutions to be very important and necessary. Even though none of the Nordic countries in the European Union has been considered effective in terms of public investment (and electricity capacity and number of employees), we assume that without the mentioned support the countries would achieve much worse results in the field of renewable resources. The European Commission (2011) states that private investors are an important element of a market-based approach to energy policy. However, as investment in the energy sector may be largely in the public interest, a mechanism needs to be found to ensure relevant state support. The promotion of renewable energy sources is also important from another point of view. Countries that have the funds to build newly installed facilities, or to operate and maintain them, will be able to replace the production of energy from non-renewable sources with renewable ones, which may also have an impact on improving the situation of Nordic states from an environmental point of view [22]. The same view is shared by Marinas et al. (2018), who state that focusing on renewable energy brings environmental but also many benefits with economic and social effects - reducing dependence on energy imports, less polluting greenhouse gas emissions, increasing employment in the energy sectors and increasing growth intensity through green technologies [23].

\section{Acknowledgements}

This publication was supported by the Operational program Integrated Infrastructure within the project: Demand-driven research for the sustainable and innovative food, Drive4SIFood 313011V336, cofinanced by the European Regional Development Fund. 


\section{References}

[1] IRENA. Innovative solutions for $100 \%$ renewable power in Sweden. Abu Dhabi: International Renewable Energy Agency, 2020. 116 p. [online] [15.02.2021]. Available at: https://www.irena.org/publications/2020/Jan/Innovative-solutions-for-100-percent-renewablepower-in-Sweden

[2] Aslani A., Naaranoja M. and Wong K.-F. V. Strategic analysis of diffusion of renewable energy in the Nordic countries. Renewable and Sustainable Energy Reviews, vol. 22, 2013, pp. 497-505, DOI: 10.1016/j.rser.2013.01.060

[3] Eurostat. Renewable energy statistics. 2020. [online] [25.02.2021]. Available at: https://ec.europa.eu/eurostat/statistics-explained/index.php/Renewable_energy_statistics

[4] Duffy A., Hand M., Wiser R., Lantz E., Dalla Riva A., Berkhout V., Stenkvist M., Weir D. and Lacal-Arántegui R. Land-based wind energy cost trends in Germany, Denmark, Ireland, Norway, Sweden and the United States. Applied Energy, vol. 277, 2020, 114777, DOI: 10.1016/j.apenergy.2020.114777

[5] Meya F., Diesendorfb M. Who owns an energy transition? Strategic action fields and community wind energy in Denmark. Energy Research \& Social Science, vol. 35, 2018, pp. 108-117, DOI: 10.1016/j.erss.2017.10.044

[6] Sovacoola B.K, Tamboa T. Comparing consumer perceptions of energy security, policy, and lowcarbon technology: Insights from Denmark. Energy Research \& Social Science, vol. 11, 2016, pp. 79-91, DOI: 10.1016/j.erss.2015.08.010

[7] Holma A., Leskinen P., Myllyviita T., Manninen K., Sokka L., Sinkko T. and Pasanen K. Environmental impacts and risks of the national renewable energytargets - A review and a qualitative case study from Finland. Renewable and Sustainable Energy Reviews, vol. 82, 2018, pp. 1433-1441, DOI: 10.1016/j.rser.2017.05.146

[8] Child M., Bogdanov D., Aghahosseini A. and Breyer C. The role of energy prosumers in the transition of the Finnish energy system towards $100 \%$ renewable energy by 2050 . Futures, vol. 124, 2020, 102644, DOI: 10.1016/j.futures.2020.102644

[9] Child M. Breyer C. The role of energy storage solutions in a $100 \%$ renewable Finnish energy system. Energy Procedia, vol. 99, 2016, pp. 25-34, DOI: 10.1016/j.egypro.2016.10.094

[10] Westholm E., Beland Lindahl K. The Nordic welfare model providing energy transition? A political geography approach to the EU RES directive. Energy Policy, vol. 50, 2012, pp. 328-335, DOI: 10.1016/j.enpol.2012.07.027

[11] Padhan H., Padhang P. C., Tiwari A. K., Ahmed R. and Hammoudeh S. Renewable energy consumption and robust globalization(s) in OECD countries: Do oil, carbon emissions and economic activity matter? Energy Strategy Reviews, vol. 32, 2020, 100535, DOI: 10.1016/j.esr.2020.100535

[12] Saint Akadiri S., Alola A. A., Akadiri A. C. and Alola U. V. Renewable energy consumption in EU-28 countries: Policy toward pollution mitigation and economic sustainability. Energy Policy, vol. 132, 2019, pp. 803-810, DOI: 10.1016/j.enpol.2019.06.040.

[13] Cross S., Welfle A. J., Thornley P., Syri S. and Mikaelsson M. Bioenergy development in the UK \& Nordic countries: A comparison of effectiveness of support policies for sustainable development of the bioenergy sector. Biomass and Bioenergy, vol. 144, 2021, 105887, DOI: 10.1016/j.biombioe.2020.105887

[14] Ministry of Foreign Affairs of Denmark. Pioneers in clean energy. [online] [27.04.2021]. Available at: $\quad$ https://denmark.dk/innovation-and-design/cleanenergy?fbclid = IwAR2caXNIvPWWL7rkD7Kefo966qPn1Xrr4QAEb378BWnM0LrZxwdV646h wxc

[15] Spodniak P., Ollikka K. and Honkapuro S. The impact of wind power and electricity demand on the relevance of different short-term electricity markets: The Nordic case. Applied Energy, vol. 283, 2021, 116063, DOI: 10.1016/j.apenergy.2020.116063

[16] Corsatea TD. Technological capabilities for innovation activities across Europe: Evidence from wind, solar and bioenergy technologies. Renewable and Sustainable Energy Reviews, vol. 37, 2014, pp. 469-479, DOI: 10.1016/j.rser.2014.04.067 
[17] Unger E. A. Elizabeth, Ulfarsson G. F., Gardarsson S. M. and Matthiasson T. A long-term analysis studying the effect of changes in the Nordic electricity supply on Danish and Finnish electricity prices. Economic Analysis and Policy, vol. 56, 2017, pp. 37-50, DOI: 10.1016/j.eap.2017.06.001

[18] Kilpeläinen S. Developing Nordic cooperation in renewable electricity policy: Exploring views from Finland and Sweden. Politics and Governance, vol. 8, no, 4, 2020, pp. 44-52, DOI: 10.17645/pag.v8i4.3408

[19] IRENA and CPI. Global Landscape of Renewable Energy Finance 2020. Abu Dhabi: International Renewable Energy Agency, 2020.88 p. [online] [27.04.2021]. Available at: https://www.irena.org//media/Files/IRENA/Agency/Publication/2020/Nov/IRENA_CPI_Global_finance_2020.pdf

[20] Sadorsky P. Wind energy for sustainable development: Driving factors and future outlook. Journal of Cleaner Production, vol. 289, 2021, 125779, DOI: 10.1016/j.jclepro.2020.125779

[21] Cicea C., Marinescu C., Popa I. and Dobrin C. Environmental efficiency of investments in renewable energy: Comparative analysis at macroeconomic level. Renewable and Sustainable Energy, vol. 30, 2014, pp. 555-564, DOI: 10.1016/j.rser.2013.10.034

[22] Európska Únia. Medziinštitucionálna príručka úpravy dokumentov. Luxemburg: Úrad pre vydávanie publikácií Európskej únie. 2011. 288 p. [online] [27.04.2021]. Available at: http://publications.europa.eu/code/sk/sk-000300.htm

[23] Marinaş M.-C., Dinu M, Socol A-G and Socol C. Renewable energy consumption and economic growth. Causality relationship in Central and Eastern European countries. PLoS ONE, vol. 13, no. 10, 2018, e0202951, DOI: 10.1371/journal.pone.0202951 